\title{
The Lives of Street Women and Children in Hawassa, Ethiopia
}

\author{
Martha A. Nathan and Elliot Fratkin
}

\begin{abstract}
Despite gains in national income, Ethiopia's cities have seen a steady increase of homeless women and children. This study focuses on the lives of twenty-five adult women and twenty-seven children living on the streets of Hawassa, Ethiopia. Nearly all were driven to the streets by poverty compounded by abuse and violence and/or loss of supporting family members, illness, and lack of social supports. The Ethiopian government offers a food-for-work program, but this is an inadequate social safety net. Recommendations include government provision of long-term shelter, food assistance, school supplies for children, legal and economic assistance, and access to medical care.
\end{abstract}

Résumé: Malgré les gains du revenu national, les villes éthiopiennes ont connu une recrudescence constante de femmes et d'enfants sans abri. Cet article examine la vie de vingt-cinq femmes adultes et de vingt-sept enfants vivant dans les rues d'Awassa dans la Région des nations, nationalités et peuple du sud d'Éthiopie (RNNPS). Presque tous ont été conduits à la rue par la pauvreté, aggravée par les sévices, la violence, la maladie et/ou la perte de soutien social ou des membres de la famille. Le gouvernement Éthiopien offre un programme

"Nourriture -pour-Travail," mais il s'agit là d'un soutien de sécurité sociale insuffisant. Les recommandations comprennent des dispositions par le gouvernement

African Studies Review, Volume 61, Number 1 (April 2018), pp. 158-184

Martha A. Nathan is an assistant professor of medicine at Tufts University and a staff physician at Baystate Brightwood Health Center, Springfield, Massachusetts. In 2011-12 she was a Fulbright Specialist teaching at the Hawassa University School of Medicine in Ethiopia. E-mail: martygj@@comcast.net

Elliot Fratkin is the Gwendolen M. Carter Chair of African Studies and a professor of anthropology at Smith College. He is a scholar of African pastoralist society and has written numerous articles and books on drought and development policy, indigenous peoples, and health and social change in Africa. He is the author of Laibon: An Anthropologist's Journey with Samburu Diviners in Kenya (AltaMira, 2012), the co-author (with Eric Roth) of As Pastoralists Settle: Social, Demographic, and Health Consequences in Northern Kenya (Springer, 2005), and the co-editor of African Pastoralist Systems (Lynne Rienner, 1994). E-mail: efratkin@smith.edu 
d'abris à long terme, d'une aide alimentaire, de matériel scolaires pour les enfants, d'une assistance juridique et économique et d'un accès aux soins médicaux.

Keywords: Urban; poverty; women's health; children; Ethiopia

\section{Introduction}

Studies of street poverty in Africa have focused primarily on street children and to a lesser extent on impoverished adults, particularly women who beg for their livelihoods. This study investigated the lives and circumstances of fifty-two homeless individuals: twenty-five adult women and twenty-seven children under seventeen years of age, living on the streets of Hawassa City in southern Ethiopia. Information was gathered through interviews and focus groups undertaken in March-June 2012. All study subjects were begging or had begged on the street, and/or worked in low-paying and often temporary street jobs.

This article argues that adult and child homelessness has increased in Hawassa. Climatic stress, including drought, and social disruption from civil wars, loss of adult providers to HIV/AIDS, and declining agricultural income have increased rural-to-urban migration. In addition, Ethiopia's transition after 1991 from a state socialist economy to a mixed state/capitalist economy achieved large economic growth which was not evenly distributed throughout the country. The article also looks at the promise and limitations of social safety nets. After the 2005 elections, the EPDRF ruling party restricted international NGO activities but also implemented a Productive Safety Net Programme addressing acute food shortages in the rural areas and more recently in urban centers.

An increasing number of studies of homelessness in Africa written by anthropologists, sociologists, public health workers, and representatives of international development agencies have focused on the experiences of the actors, the urban poor. Several point to the initiative and personal agency of individuals and families seeking physical security and alternate livelihoods (see, e.g., Abebe 2008; Kilbride et al. 2001; Heinenon 2011). Our study, while recognizing a degree of agency shown particularly by urban youth, and to some extent by adult women, reveals the lives of relentless hunger, violence, illness, and psychological stress brought about by extreme poverty. This article examines the effects of street poverty on women and children, their similarities and differences, and how connections to social networks, including other beggars as well as family members, can offset hardships. We situate their stories in the context of existing and absent social services provided by the Ethiopian government, the Orthodox Church, and international NGOs. We conclude with a discussion of policy recommendations that point to the need for more government efforts with less reliance on nonstate players to deal with the problems of urban poverty and homelessness. 
Impoverishment and urban begging are not new in Africa, but they have become an increasing problem and constitute an embarrassing challenge to local and national state governments (see figure 1). In the past, human communities living in rural areas faced periodic disasters and dislocations caused by warfare, drought, slave-raiding, and disease (Iliffe 1987). Twentieth-century colonialism contributed to further disruptions, particularly in rural areas in East and southern Africa where populations were displaced for settler farms or coerced into migrant labor for mines, factories, and plantations (Berman \& Londsdale 1992; Freund 1996). Urban migration and urban poverty have increased steadily in the postcolonial era. By 2010, 36 percent of the continent's population lived in or around large cities; it is expected that 50 percent will be urbanized by 2030 (World Bank 2015a).

Not all street beggars are homeless, and not all homeless people are beggars. The concept of homelessness emerged with urban poverty in North America and Western Europe. Tipple and Speak (2003) point out that poverty may be a continuum of experiences, which may or may not refer to physical structures, and may or may not include the nexus of social relationships that tie people to a "home." For this reason, we prefer the concept of "street poverty," rather than the term "homelessness." These individuals may work in low-income street jobs, beg for sustenance, or engage in prostitution or criminal activities to survive. For the most part,

\section{Figure 1. Young mother with two children, Hawassa}

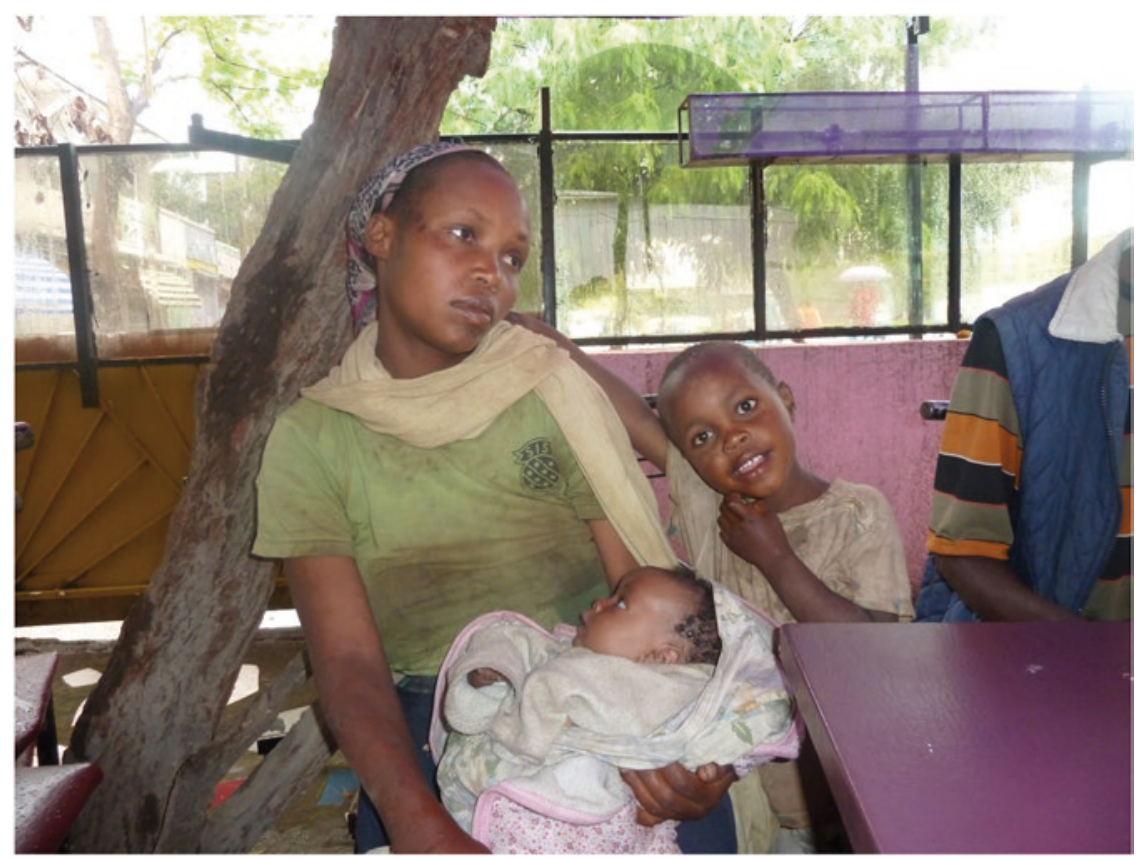


national and metropolitan governments throughout the continent have not assisted these people with meaningful social safety nets. Rather, they have often resorted to periodic "street sweeping" of the homeless from sight in the prosperous business and residential neighborhoods, particularly when facing an influx of international visitors (Human Rights Watch 2014).

Research on homelessness in Africa has focused largely on street children, with characterizations ranging from their vulnerability and victimization (UNESCO 2015) to descriptions of their autonomy and maintenance of social networks (Abebe 2008; Kilbride 2010; Kilbride et al. 2001; Heinenon 2011; Panter-Brick 2000). However, to many residents in African cities, children who beg on the streets appear as delinquent, risky, or "gone outside childhood" (Connolly \& Ennew 1996:133), and they are frequently chased away or beaten by police, shopkeepers, or other pedestrians.

Less has been written about adult street women or men in Africa. Several studies from South Africa discuss health and poverty when poor living and housing conditions intensify the vulnerability of women to certain environmental and health risks. Here poverty means "having no property, no house, no money, no job, no parents, no food, no clothing, no hope, isolation, suffering and exclusion" (Olufemi 1999:485). There is a strong relationship between adult homelessness and the rapid spread of HIV and AIDS in South Africa (Phiri \& Perron 2012). The situation in Ethiopia, while similar in kind, has its own particularities.

\section{Homelessness in Ethiopia}

Although never truly colonized (except for brief rule by Italy in 1936-41), Ethiopia endured imperial and feudal rule under Menelik II (1889-1913) and Haile Selassie (1930-74), which resulted in rural servitude and periodic dislocation. The socialist regime of Mengistu's Derg (1974-91) broke up large feudal estates, but it also created large state farms and resettled numerous households from rebellious areas, including the north and less populated regions in the west and south (Bahru 2001; Marcus 2002). While there were beggars under both the Selassie and Mengistu regimes, they were less conspicuous than today and would visit individual houses or Orthodox churches to obtain clothing and food. Whereas Uganda and Kenya turned to international NGOs to provide social services following the structural adjustment policies of the 1980s, Mengistu regulated NGOs, allowing only a few famine relief organizations during the famine of 1983-85 (Barrow 2001). Mengistu created some relief structures, including a Children's Village at Alage south of Addis Ababa to serve children whose fathers died in the 1977-78 Ethio-Somali War; this was converted to a technical and agricultural college following Mengistu's overthrow (Walalign Tadesse, personal communication).

Mengistu was overthrown in 1991 by the Tigray Peoples Liberation Front (TPLF) and the Eritrean Peoples Liberation Front (EPLF), leading to the separation of Eritrea from Ethiopia. Meles Zenawi, former leader of the TPLF, 
created a new government ruled by the Ethiopian People's Revolutionary Democratic Front (EPRDF). (Meles was succeeded at his death in 2012 by Hailemariam Desalegn). The visibility of urban begging increased after 1991 as Ethiopian soldiers were demobilized, civil servants were laid off, and Ethiopian refugees poured in from Eritrea. The migration of rural poor into cities increased due to several factors: periodic drought and decreasing rainfall, population growth, land fragmentation, adverse coping strategies (the selling of land, livestock, and other assets), rising food prices and falling crop prices, unequal access to markets, political violence, and the death of adults from HIV/AIDS (Abebe 2008; Dercon \& Krishnan 2000; Dercon et al. 2012; Roelen \& Camfield 2014). Urban displacement with new construction also led to some homelessness (Ynitso 2008).

The EPRDF government did create certain social welfare programs, in line with its revolutionary promises to improve the quality of life for ordinary Ethiopians. The government established a Ministry for Women, Children and Youth Affairs with administrative offices at kilil (regional), woreda (district), and kebele (municipality) levels. This body was responsible for promoting women's employment (particularly in construction), microfinance, feeding programs, the prevention of abuse and neglect, the provision of some assistance to widows and impoverished families, and the supervision of child adoptions (Government of Ethiopia 2015).

Initially Meles welcomed international NGOs to assist with social welfare and development programs (Campbell 2001), although these organizations were often relegated to areas of political influence such as the Tigray region in the north. These NGOs lost standing and faced new restrictions following the election of 2005 when Meles nearly lost power and blamed various NGOs for aiding opposition parties (Abbink 2006). While protecting the livelihoods of small peasant farmers in the highlands, the EPRDF's political base, the government promoted large-scale agribusiness in the less-populated lowland regions. These large farms (2000 hectares or more) were owned by the state, private individuals, and foreign corporations (the outcome of so-called "land grabbing"). They displaced indigenous peoples and smallholders to produce rice, cotton, sugar, biofuels, and cut flowers, much of it for export (Fratkin 2014; Futures Agriculture 2006; Human Rights Watch 2012; Little 2014; Oakland Institute 2011). While these large farms helped increase Ethiopia's GDP to USD550 per person, 82 percent of Ethiopia's 96 million people continued to live as smallholders with farms smaller than two hectares. Today 30 percent of Ethiopia's population live on less than USD1.25 purchasing power parity (PPP) per day-although as the World Bank notes, this was a significant improvement from 2000, when 56 percent of the population lived at this income level (World Bank 2015b).

\section{The Productive Safety Net Programme (PSNP)}

In 2005 Ethiopia initiated the Productive Safety Net Programme (PSNP) aimed at ensuring food security in rural areas facing increasing risks of 
drought and climate change (World Bank 2009). The Ethiopian government acknowledged that half of the rural population received less than $2000 \mathrm{kcal}$ per person daily and faced periodic or chronic food shortages brought about by poor harvests, rainfall shocks (drought or flood), and disease, especially malaria and HIV/AIDS (Government of Ethiopia 2010:4). The PSNP provided several levels of support to the rural poor: (1) cash or food to disaster areas or chronically food insecure households (mainly delivered by international NGOs including CARE, World Vision, Family Health International, and the U.N. World Food Programme); (2) conditional transfers providing cash or food for public works including the building of roads and government buildings, and soil conservation (the so-called "food-for-work" program); and (3) unconditional transfers or direct support (DS) if the households had no means of support or consisted of members who could not work, including the disabled and breast-feeding mothers.

The PSNP was strongly touted by the World Bank (2009, 2016) for providing a social safety net to Ethiopia's most vulnerable people. Britain's Overseas Development Institute (ODI) criticized the program's weaknesses, however, noting that very poor households, including female-headed households living on direct support, did not have enough food for each month, nor were they able to support their families with "food-for-work" that typically offered only five days' work per month at a rate of USD1.00 per day (ODI 2006). While some of the original Productive Safety Net Programme was directed at urban areas, it did not serve homeless or street women and children. In December 2015 the World Bank pledged USD300 million International Development Association (IDA) credit to Ethiopia for the Urban Productive Safety Nets Project (UPSNP), but again there was no specific inclusion of homeless or street people as targets of assistance (World Bank 2015c).

\section{Previous Studies of Homelessness in Ethiopia}

Dube's (2014) study of urban poverty in Bahir Dar noted that adult women made up one-third of the homeless population while boys under eighteen years constituted over half. All were poor and many came directly from rural settings. Mushir's (2012) study of homelessness in Mekelle in northern Ethiopia found 72 percent of the homeless population was illiterate or barely educated. Many (52 percent) had arrived directly from the hinterlands and earned their livings in casual/day labor, transportation, or petty trades. Some women worked in restaurants and as housemaids, and passed their lives in rented houses, slums, and along the roads where civic amenities were either absent or minimal. Other studies have pointed to mental health problems of the homeless, noting that few medical services are provided or made available to them (Fekadu et al. 2014). Others have written about the stigma street children bear. Heinonen (2011) writes, 
In Ethiopia, the public assumes that street children are more or less outside the direct guidance, moral inculcation and economic dependence of their parents. ... They perceive homeless youth gang members who do not live with their families as being juvenile delinquents, prostitutes, drug abusers, petty thieves, vagrants, dropouts, and deviants. (2011:3)

One of the most detailed studies is Abebe's (2008) seven-month study of sixty street children in Addis Ababa, which found that much of their income was derived from begging or casual work, which provided resources essential to their families' livelihoods. Almost half (46 percent) were living with stepparents since their biological parents had died or were divorced or separated; most children reported that their stepfathers, and sometimes stepmothers, were physically abusive. Many had parents who were disabled (blind, lame, mentally disabled). Abebe argued that the number of ablebodied impoverished people who beg in the streets and in the mosque and churchyards is increasing; many youthful beggars conceal their situation from their schoolmates, as it is considered shameful and dirty.

\section{Hawassa Setting}

Hawassa is the regional capital of the Southern Nations and Nationalities Peoples' Region (SNNPR), located on Lake Awasa, which is part of the Rift Valley chain of lakes in southwest Ethiopia. The largest city in southern Ethiopia, it is located $270 \mathrm{~km}$ south of the national capital, Addis Ababa. SNNPR is an agricultural region noted for its coffee and ensete (false banana, a food crop). In 2006 Hawassa city's urban population was 157,879, while the larger Hawassa Zone (including surrounding peri-urban communities) was 258,808 (Central Statistical Agency 2007). The five largest ethnic groups are Sidama people (49 percent), Amhara (15 percent), Welayta (14 percent), Oromo (5 percent), and Gurage (4 percent); nearly 60 percent of the population practices Evangelical Protestantism, 27 percent identify as Ethiopian Orthodox Christians, 8 percent are Muslim, and 3.8 percent are Roman Catholic, according to the 2007 census (Central Statistical Agency 2007).

\section{Methods}

This study of street women and children was undertaken by two U.S. Fulbright scholars teaching at the University of Hawassa in 2011-12, a medical doctor teaching at the Hawassa Referral Hospital (Nathan), and a visiting professor of anthropology at the university (Fratkin). The study was provoked by an early-morning bicycle ride by Nathan to her work at the hospital, during which she noted a young boy, about eight years old, arising from beneath a culvert over a gutter, where he obviously had just spent the night. The study was planned to explore the reasons for child and female homelessness and reliance on begging in the town and the methods of street survival (see figure 2). Women of child-bearing age and older and 
Figure 2. Young children playing in culvert, Hawassa

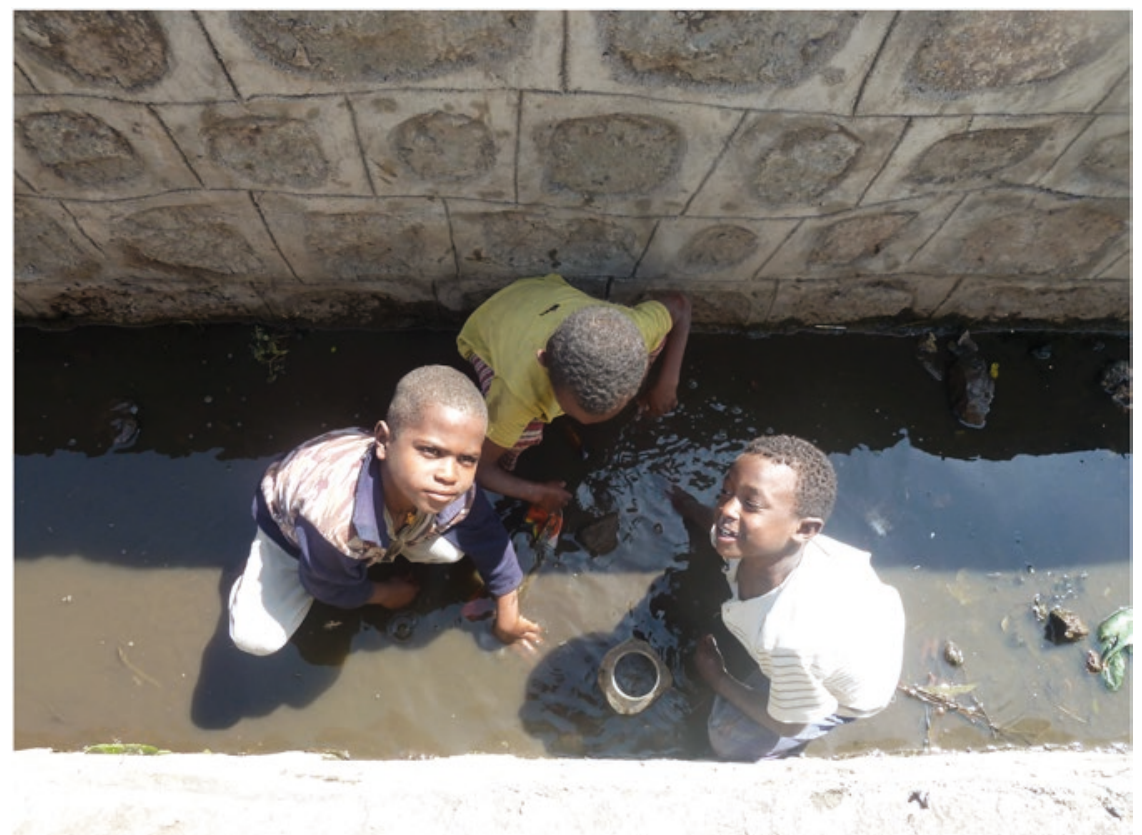

children sixteen years and younger (sometimes the children of the female subjects) were approached on the streets of Hawassa between April and June 2012 and asked if they would answer questions about their lives. Selection of the subjects was not random. They were identified at places where begging was known to occur: in front of two of the Orthodox churches in town, near the lakefront, in front of the local university, and near the Referral Hospital. An attempt was made to reach those begging in different parts of the city. While some of the women had small children, most of the street children were independent, although several had families with whom they had some relationship.

Martha Nathan conducted interviews with a young male student assistant who spoke Oromo and Amharic and was highly sympathetic to the plight of our subjects. At times it was necessary to use a second interpreter who spoke Sidamo or other languages. In return for their cooperation, women and children were given a meal during the interview. In addition, children were paid 20 birr (USD1.33) each and women were given 100 birr (USD6.66), substantial sums compared to their daily earnings. Most were interviewed in focus groups of two to four friends over a two-hour period. Women and children generally were interviewed separately. Focus group techniques followed similar qualitative methodologies that have been employed in Ethiopia (Tekola et al. 2009) and previous research in northern Kenya (Nathan et al. 2005). Questions included ethnic and geographic 
history, family histories, and how the interviewees came to live on the streets of Hawassa.

Questions were added over time, including one about the daily wages of begging. Others were eliminated-about prostitution, drugs and alcohol, and the commission of crime such as burglary or theft-as it became clear that interviewees were hesitant to respond in front of others and answers did not seem to be reliable. Answers were recorded in writing at the time. When we learned about the existence of a tin-roofed bamboo-walled compound called Qrchu, built by the municipality in 2010 in order to house the burgeoning homeless population on the eve of the fiftieth anniversary celebration of the city and remove their "street structures" from downtown, Nathan held nightly informal medical clinics there for those without access to medical care. Medicines were dispensed, and two women were triaged for treatment at the Referral Hospital Clinic.

\section{Results: Street Women}

Twenty-five women whose ages ranged from fifteen to seventy-five were interviewed. (Major results are listed in table 1). The average age was thirty years. Fifteen women came from outside a twenty-mile radius of Hawassa, with the majority having migrated from the Sidama area of SNNPR. The time that they had spent on the street varied considerably, from one month to thirty-eight years, averaging almost six years.

Marital status. Eight women were married and living with their husbands at the time they were interviewed. Six of the eight husbands were disabled and begging. The rest of the spouses were impoverished and doing street jobs while also begging. Four women had never married. Thirteen were widowed or separated/divorced from their husbands.

Children of street women. The twenty-five women had borne fifty-six children, of whom four had died, one had disappeared and never been found, three had been adopted by non-family members or were living with other relatives, and seven were grown and independent. The average number of living children per woman was 2.0 and collectively they were caring for forty-one children, or 1.6 per woman.

Reason for life on the street. Three women were "born on the street" to parents who were begging. Among the others, the most common reasons for their homelessness and impoverishment were their husband's disability or death (48 percent), abandonment by their husband/partner (32 percent), violence from their husband or partner, or a husband's alcoholism. For all the women interviewed, at least one of these crises, and often more than one, had precipitated their turning to the street. However, that decision was made in the context of lack of long-term economic and family support. Thirteen women had suffered the death of at least one parent during childhood, and all but one said as well that their natal families were "poor" and could not support them. 
Table 1. Street Women and Children Attributes

\begin{tabular}{|c|c|c|c|}
\hline & & Women $n=25$ & Children $n=27$ \\
\hline \multirow[t]{3}{*}{ Demographics } & Avg age (yrs) & 30 & 10.7 \\
\hline & Time on street (yrs) & 5.8 & $3.6 *$ \\
\hline & Born locally & $10(40 \%)$ & $17(63 \%)$ \\
\hline \multirow[t]{4}{*}{ Marital Status } & Married & $8(32 \%)$ & $\mathrm{n} / \mathrm{a}$ \\
\hline & Widowed & $6(24 \%)$ & $\mathrm{n} / \mathrm{a}$ \\
\hline & Separated & $7(29 \%)$ & $\mathrm{n} / \mathrm{a}$ \\
\hline & Single & $4(16 \%)$ & $\mathrm{n} / \mathrm{a}$ \\
\hline \multirow[t]{2}{*}{ Schooling } & Ever in school & $4(22 \%) * * *$ & $21(88 \%) *$ \\
\hline & Avg Years of school & $.67^{* * *}$ & $2.3^{*}$ \\
\hline \multirow{8}{*}{$\begin{array}{l}\text { Factors Leading to } \\
\text { Street Life }\end{array}$} & Born to begging parents & $3(12 \%)$ & $12(44 \%)$ \\
\hline & Family very poor & $24(96 \%)$ & $21(88 \%)$ \\
\hline & Death of parent & $13(52 \%)$ & $15(56 \%)$ \\
\hline & Violence by husband or parent & $7(28 \%)$ & $8(30 \%)$ \\
\hline & $\begin{array}{l}\text { Partner abandoned/parents } \\
\text { separated }\end{array}$ & $8(32 \%)$ & $20(74 \%)$ \\
\hline & Partner disabled & $6(24 \%)$ & $\mathrm{n} / \mathrm{a}$ \\
\hline & Partner alcoholic & $5(20 \%)$ & $\mathrm{n} / \mathrm{a}$ \\
\hline & Partner died & $6(24 \%)$ & $\mathrm{n} / \mathrm{a}$ \\
\hline \multirow[t]{4}{*}{ Shelter } & Pavement or street shelter & $8(32 \%)$ & $20(74 \%)$ \\
\hline & Sidama house & $4(16 \%)$ & $2(7 \%)$ \\
\hline & Rented room & $1(4 \%)$ & $0(0 \%)$ \\
\hline & Homeless housing, $\%$ & $13(52 \%)$ & $5(18 \%)$ \\
\hline \multirow[t]{8}{*}{ Support } & Begging & $24(96 \%)$ & $24(89 \%)$ \\
\hline & Begging with child or parent & $20(84 \%)$ & $3(11 \%)$ \\
\hline & Working & $6(24 \%)$ & $19(70 \%)$ \\
\hline & Ever worked & $16(64 \%)$ & $20(74 \%)$ \\
\hline & Church & $22(88 \%)$ & $15(55 \%)$ \\
\hline & Parental support & $1(4 \%)$ & $14(51 \%)$ \\
\hline & Support from children & $1(4 \%)$ & $\mathrm{n} / \mathrm{a}$ \\
\hline & $\begin{array}{l}\text { Average income } \\
\text { (Ethiopian birr/day) }\end{array}$ & $8.5 \$$ & $15 \$ \$$ \\
\hline \multirow[t]{5}{*}{ Hardships on the street } & Hunger & $24(96 \%)$ & $27(100 \%)$ \\
\hline & Threats, theft or violence & $15(60 \%)$ & $21(78 \%)$ \\
\hline & Illness or disability & $21(84 \%)$ & $9(33 \%)$ \\
\hline & Lack of medical care & $13(62 \%) \$ \$ \$$ & $6(25 \%) *$ \\
\hline & Problems with police & $13(60 \%) \&$ & $11(39 \%)$ \\
\hline
\end{tabular}

$* n=24, * * n=23, * * * n=18, \$ n=8, \$ \$ n=5, \$ \$ n=21, \& n=22$

Two of the women told stories of abandonment by boyfriends who had impregnated them and then left when told of the pregnancy. One woman had been abandoned by the family of her husband when he died while she was pregnant. Another woman told of being left by her husband to work in a mine when she was pregnant. He never came back, and she was told by an 
acquaintance that he had been killed in a mining accident. She received no compensation, lost her housing, and moved to Hawassa to work and ultimately to beg with her infant.

School. The average number of years of schooling per woman was less than one, with most (11 of 18) who were asked never having entered school. The highest level of education attained by any woman was the fourth grade. Thus the collapse of a relationship with a spouse or lover occurring to a woman without financial, family, or educational resources meant begging as one of few viable alternatives.

Goals for the street. Among the women who were not born on the street and not from Hawassa, one-half of those who were asked specifically about their objectives said that they had come to the city looking for a job. Onequarter said that they came specifically to beg, with three women looking for treatment for disease such as HIV and mental illness (in one case for the woman's husband).

Shelter. Four of the twenty-five, including two with children, were sleeping in the open with no shelter at all. Three lived in grass-covered Sidama-style houses just outside the city and traveled to town by foot or bus regularly in order to beg. Four women lived in "street shelters" made of burlap and plastic and sticks on the pavement either outside one of the Orthodox churches or in the market. Only one rented a room in the city for 3 birr (USD0.16)/ night.

The largest group (13 of the 25) had been moved by the municipality into "homeless housing," either Qrchu or a smaller site at the downtown St. Gabriel's Orthodox Church. All the women in such housing had previously lived on the pavement (see figure 3). Several women described being taken by trucks from their downtown street shelters in the middle of the night, without warning, to their new home approximately one mile away. The housing at Qrchu and St. Gabriel's was more permanent, with wooden poles holding up tin roofs but with walls of burlap outside and inside creating apartments for families. Some of the apartments reportedly housed up to eleven people. At Qrchu there was outdoor running water and an outhouse.

Begging, work, and other support. All but one woman were begging in one or many forms: sitting on the sidewalk asking passersby for money, walking house-to-house begging for food or money, or going to restaurants asking for leftover food. All women were begging with small children if they had them or had done so in the past when their offspring were younger.

The one woman who was not begging had been born on the street, had begged with her family or independently all her life, and two years prior to the interview had stopped because she and her husband could support their family through low-wage work. She continued to live at Qrchu, however.

Eight women were asked how much they made in a day of begging. Using the highest figure given by each woman, the average was 8.5 birr, or slightly less than USD0.50 at the 2012 exchange rate. The most earned was 10-15 birr/day (USD0.57-USD0.85), reported by two women who begged with their toddlers. 
Figure 3. Shelter structure on Hawassa street

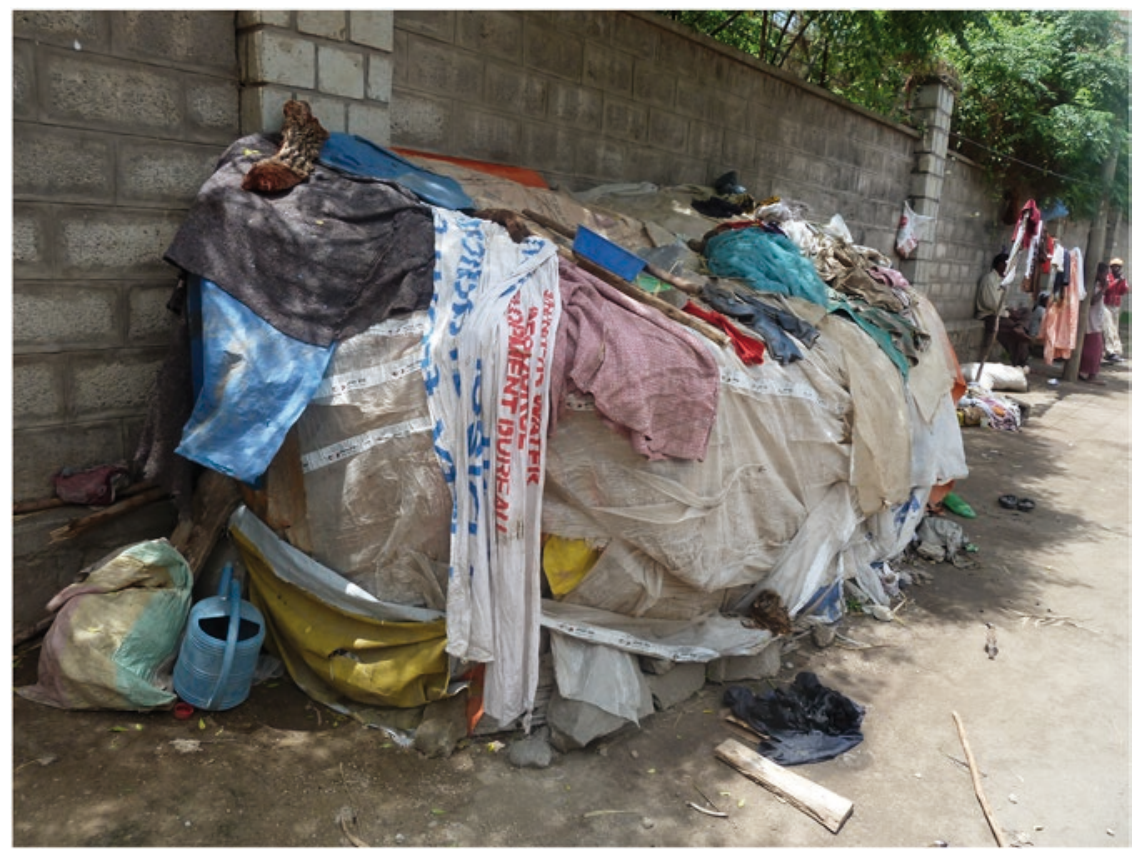

Five women were relying on both work and begging to survive at the time of the interviews, but sixteen women had worked at some point in their lives. Two women who had homes on the outskirts of the city raised ensete (false banana) and others washed clothes, baked enjera (Ethiopian teff-based flatbread) for sale, cleaned dung out of the yards of private houses, or sold sugarcane on the street. Several women had in the past worked as servants.

The main other source of support was the Ethiopian Orthodox church (and for one the Protestant church), which routinely gave food and clothes at Christmas and Easter. Twenty-two women reported receiving this charity. Some women living near the local Orthodox church were receiving water and housing and schooling for their children. Four women reported that they received flour and oil from the municipality. Two older women reported that in the past the town had given them money.

Women were not questioned about the exchange of sex for money or for food, as ultimately this was not considered appropriate in public space discussions, particularly with strangers.

Hardship on the street. All but one of the twenty-five (the young woman who had stopped begging) said they were sometimes or always hungry. One woman with HIV infection stated that she had difficulty taking her medications because, though she had access to the pills, she frequently did not have food with which to take them. 
Most women had to use some of their scant earnings to buy water from shopkeepers to drink and to bathe in. Some women bathed regularly in Lake Hawassa, though that practice was formally banned by the city. Urination and evacuation occurred on the street or in dug latrines.

Twelve women stated that they had suffered theft on the street, four reported violence against them, including rape, and another five said they had received serious threats of violence or rape. Overall, 60 percent had suffered from either threats, violence, theft, or a combination.

Many said that they were protected by local shopkeepers and security guards. However, their relations with police were more complicated. Twentytwo were queried about the police. Of those women, thirteen saw the police negatively-either unwilling to protect them or chasing them when begging - whereas nine viewed them benignly or as a source of protection. One woman described being protected by police officers from a threatened rape while another reported being beaten by them for begging.

Twenty-one women (84 percent) described serious chronic or recurrent illnesses ranging from HIV infection (3 women) to epilepsy, severe depression, a disabling leg injury, or an undiagnosed cough. Only slightly more than one-third of those reporting illness said that they had ever visited a medical provider in their time on the street, either a local clinic or the Referral Hospital. Of the two women seen at Qrchu who were triaged for treatment at the Referral Hospital Clinic, one had untreated HIV infection and the other had metastatic cancer.

Fourteen women were asked if they liked their existence on the street, and their answers were unanimously and emphatically "No." One woman said angrily that she wanted "to get out of this mess." Another commented, "Only wild animals live on the street." A third said she would "rather die than continue living on the street." Women described fear, embarrassment, hopelessness, hunger, discomfort, and exposure to sun, cold, and insults.

Children's healthcare and schooling. In contrast to the lack of personal medical services obtained by these women, of the twenty women with dependent children, nineteen had sought and received health services for their children. Their success at attaining schooling for their children was more limited. Of the twenty-two children of school age or older born to these women (excluding those who had been adopted out or were deceased or missing), only seven were still in school. Seven had never gone to school, and eight had left school after one to three years. Reasons given by mothers for their children dropping out were lack of money for supplies, pressure from the father to force the child to leave, and the child's illness. Thus, though the children were more likely than their mothers to have attended some school, most had never attended or had rapidly dropped out and none had finished (see table 2).

The future. When asked their hopes, most of the women (16) mentioned their wish for jobs to support themselves, frequently stating that they would like to be in business. Twelve mentioned their desire for a permanent home and education for their children. Two women dreamed of owning animals for milk and meat. 
Table 2. Offspring of street women

\begin{tabular}{lc}
\hline Total offspring & 56 \\
Number children/woman & 1.6 \\
Lost or died (\%) & 9 \\
Adopted (\%) & 5 \\
Independent (\%) & 12 \\
Living with mother (\%) & 74 \\
Preschool (\%) & 50 \\
School age or older (\%) & 34 \\
School age or older, in school now (\%) & 35 \\
School age or older, ever in school (\%) & 50
\end{tabular}

\section{Results: Street Children}

The ages of the twenty-seven interviewed children ranged from five to seventeen years, with an average age of 10.7 years. The children tended to be more certain of their ages than the women interviewed in this study. Four of the twenty-seven, or 15 percent, were girls. The children were more likely than the interviewed women to have been born within a twenty-mile radius of Hawassa: seventeen (63 percent) were born locally. Information on how long they had spent on the street was recorded for twenty-four of the children; the rest were unsure. The span of time on the street ranged from two months to eight years (with an average 3.6 years). Thus on average a child had spent more than one-third of his or her life on the street (see table 3).

Seven, or 27 percent, of the children had spent their entire lives on the street, born to women who were begging at the time. For those not born on the street for whom information was available, the average age of turning to the street was 9.9 years, ranging from age seven to a recently-arrived thirteen-year-old.

Status of parents. More than half of the children (15 of the 27, or 56 percent) had suffered the death of at least one parent (or in one case, the death of a stepparent who was the caretaker). Of those fifteen who had lost parents to death, all but one of the remaining parents were described as poor. For the one exception, the child's widowed father (who, the child claimed, had abused his mother and caused her to leave him) had remarried and the child and his stepmother quarreled. Twenty-four of the twenty-seven children described their family as "very poor," and half of those had a parent who begged. The impoverished parents otherwise worked as farmers, toiletdiggers, or if single women, baked and sold enjera from house to house.

Only seven of the children had parents who lived together. Another seven had parents who had separated, and the children lived with their mothers. Though they were not asked specifically about parental alcohol abuse, four of the children mentioned that their fathers were alcoholics. Two of the children knew that their mothers were suffering from HIV infection. 
Table 3. Street Children attributes by origin

\begin{tabular}{|c|c|c|c|c|}
\hline & & $\begin{array}{l}\text { a. Born on } \\
\text { Street (a) } n=7\end{array}$ & $\begin{array}{l}\text { b. Living with } \\
\text { parent } n=5\end{array}$ & $\begin{array}{l}\text { c. Independent } \\
\mathrm{n}=15\end{array}$ \\
\hline & Avg age (yrs) & 6.3 & 11.6 & 12.5 \\
\hline & Time on Street (yrs) & 6.3 & 4.5 & 2.4 \\
\hline & Born locally $(\%)$ & 100 & $60 \%$ & 40 \\
\hline \multirow[t]{4}{*}{ Schooling } & $\begin{array}{l}\text { School age or greater } \\
\text { (\# of children) }\end{array}$ & 4 & 5 & 15 \\
\hline & $\begin{array}{l}\text { Ever in school if old } \\
\text { enough }(\%)\end{array}$ & 50 & 100 & 93 \\
\hline & $\begin{array}{l}\text { Average time in } \\
\text { school (yrs) }\end{array}$ & 0.5 & 2.8 & 2.7 \\
\hline & Left or never went $(\%)$ & 100 & 40 & 93 \\
\hline \multirow[t]{6}{*}{ Why on Street } & Death of parent (\%) & 86 & 40 & 47 \\
\hline & Family very poor (\%) & 100 & 100 & 80 \\
\hline & Parents not together (\%) & 86 & 100 & 60 \\
\hline & Violence in home (\%) & 29 & 0 & 40 \\
\hline & Parents begging (\%) & 100 & 80 & 6 \\
\hline & Lack of support (\%) & 100 & 100 & 100 \\
\hline Shelter & $\begin{array}{l}\text { Pavement or street } \\
\text { shelter } \%\end{array}$ & 71 & 0 & 100 \\
\hline \multirow[t]{2}{*}{ Support } & Begging (\%) & 100 & 80 & 87 \\
\hline & Working (\%) & 14 & 80 & 94 \\
\hline \multirow[t]{4}{*}{$\begin{array}{l}\text { Difficulties } \\
\text { on Street }\end{array}$} & $\begin{array}{l}\text { Suffered violence, } \\
\text { theft or threats (\%) }\end{array}$ & 71 & 80 & 80 \\
\hline & Illness or disability (\%) & 29 & 40 & 40 \\
\hline & Hungry $(\%)$ & 100 & 100 & 100 \\
\hline & Problems with police $(\%)$ & 0 & 14 & 63 \\
\hline
\end{tabular}

Nine of the twenty-seven children still lived with one parent-eight with their mother and one, whose mother had died, with his father. This group included four who were born to mothers who were begging at the time and continued to live with them. The other eighteen children had left their parents and were living on the street.

Reason for life on the street. Asked about their reasons for being on the street, every child mentioned inadequate support at home-lack of food, clothing, and shelter. This was true even for three children who did not specifically describe their parents as poor; two of these mentioned remarriage of the supporting parent after parental death or separation as a factor. One specifically mentioned quarrels with the stepmother and the other, an eleven-year-old boy, said that his father, who was employed as a security guard at the university, had stopped supporting him after his remarriage. The third child, a small twelveyear-old boy, stated that his parents beat him and were unwilling to support him and that his older brothers in a rural town had been killed by "gangsters." 
School. Four of the children were going to school at the time that they were interviewed. Three of them still lived with one parent. The fourth was a remarkable fifteen-year-old boy who had gone back to school while sleeping in a clothing bag on the street. He was in fifth grade, studied under the street lights at night, and washed cars and begged to support himself.

Of the remaining twenty who were old enough, three had never been to school at all and two, who were teenagers, had attended school through the sixth grade before leaving their homes to work and beg on the street. The average number of years of schooling for the entire group was only 2.3.

Not all were asked why they had never gone to or had left school. Almost all who were asked identified poverty-inability to pay for shoes or school supplies - as the reason. One boy stated that his mother, who herself begged in front of the church, beat him when his pair of shoes was stolen at school. Four of the older boys stated that they left school as part of leaving their homes in the countryside to come and work on the streets. Only one child left school because he did not understand the lessons, though another child born on the street said he was treated badly by other children.

Goals on the street. Fifteen children who were at least eight years old were asked what they were looking for when they came to the streets of Hawassa. All but one were searching for jobs. That one child said he was looking for a place to stay with a relative (whom he never found).

Shelter. Sleeping arrangements varied among the children, mainly depending upon their relationship to their families. Seven of the nine children who lived with a parent slept in a permanent structure. The exceptions were the children of beggars: the five-year-old whose mother had died and who lived with his father in a street shelter next to the town dump and the six-year-old girl who had been born on the pavement and continued to live with her mother without shelter.

Fifteen of the children had no reliable shelter. They tried to sleep under shopkeepers' awnings but were often chased away by the owners or by police. Sometimes shopkeepers would also keep their possessions-blankets, cups, toothbrushes-while they worked or begged during the day. Three boys who were friends shared a street shelter for which they paid 2 birr/night (USD0.11).

Begging, working, and support. The clear majority-twenty-four of the twenty-seven children interviewed-said that they begged for money on the street, three of the younger ones with their mothers. One child had begged in the past but had stopped. Many children over the age of eight had "street jobs" selling individual cigarettes or toothbrushes, carrying heavy burdens on the street, in the market, or at the bus station, washing dishes, shining shoes, or cleaning cars. Two boys had come from the countryside specifically to sell toothbrush sticks that were sold to them by an adult. One young man had been given a shoe shine kit by a foreigner who wanted to help him, but the kit was stolen and he was forced to revert to cleaning cars and begging. Most of the children had been given food and clothing by the Orthodox church on Christian holidays, which was the only institutional 
support identified. We did not ask about criminal incomes such as theft and burglary, which they are often accused of by the public.

Several of the boys working street jobs stated that they did not beg on the street for money but would beg for food and clothes to supplement their jobs. Many said that they begged for food leftovers from restaurants or would buy it very cheaply. Children were more likely than the women to identify shopkeepers as supportive for holding their limited possessions, but that may have been because women were more likely to live in permanent structures. Of the five boys who were asked how much they made in a day between working and begging, the answers ranged from 5 to $30 \mathrm{birr} /$ day, the latter sum from two of the older teenage boys who washed cars and acted as porters in the bus station. The group average was thus just over $15 \mathrm{birr} /$ day, or approximately USD0.85.

Hardship on the street. All twenty-seven street children said that they were sometimes or always hungry, one stating he sometimes went all day without eating. We did not attempt to investigate gangs among the youth, but the issue came up when children were asked about what they feared on the street. Twenty-one children (78 percent) stated that they had suffered threats, theft, or violence. Many complained of adults chasing them from gathering places or shelters, sometimes beating them. Younger children complained of "gangsters" stealing or extorting money and food. We witnessed one child (who had not complained of threats or violence) to whom we gave food being threatened and attacked by larger boys. Some younger children, though, also spoke of protection by older street boys.

Nineteen children were asked about use of drugs, but only three admitted to chewing khat, a stimulant grown in Ethiopia that helps suppress hunger. Interestingly, those were the same three young teenage boys who, when asked about friendships, described a group of ten boys who hung out together under the leadership of M, a thirteen-year-old. One child, though, when asked what he disliked about the street, complained of other street kids who were addicted to drugs. Thus, both gangs and drug use may have been more common than our limited study could detect.

Of the twenty-three children asked, thirteen children said the police treated them well enough, some stating that police protected them. However, one stated that the police beat street children, and three complained that the police had at some point sent them home to the countryside (though they obviously had returned).

Though nine children identified illness or disability-frequent colds, prolonged cough, "problem with kidneys," high fever, head injury from being hit by a taxi, and a permanent hand injury-only six could remember having gone to a doctor for treatment. Sixteen of the children could remember that they had had immunizations. Three of the smaller children described taking pills that they found on the street.

Ten children were asked if they liked being on the street. They were unanimous in their negative response, complaining of hunger, cold, dirt, and fear. One stated that life on the street is "like hell." Everyone stated that 
there were at the time many more street children than previously, and thus fewer jobs.

The future. Despite their fears and dislike of the street, many had dreams. Nine said that they wanted to be doctors. Others wanted to be teachers and merchants. The two oldest boys, though, grounded their hopes in reality, like the women interviewed. They just said that they wanted a job and to be off the street.

The most poignant answer came from the five-year-old son of a begging mother: "I want to grow up."

In order to understand the effects of the different influences leading to child street life, it was helpful for us to divide the children into three groups. The first group consisted of those "born on the street" to mothers who were begging at the time. These children were second-generation street kids. The children of the second group were those not born on the street who still were staying with a parent and were begging or doing street jobs. Most were on the street due to break-up of an impoverished family and the inadequacy of the mother's income. The child's income from begging or street jobs was a supplement. The third group consisted of mostly independent children who had left their homes, lived on the street, and begged and did street jobs. Their parents were alive and maintained a home but were too impoverished to support their children.

Born on the street. The seven children who were "born on the street" had been begging all their lives starting in their mothers' arms. They were younger than the mean of the sample, with an average age of 6.2 years. All were from the Hawassa area, and all but one had suffered the death of a parent, a father in five of the six cases. Two of those born on the street were girls. Two of the little boys were friends who had left their mothers-in one case because the begging mother beat him-and were living and begging on their own. Each had left school in his first year due to lack of funds for shoes and supplies. They slept together under a street awning with other boys. These two were interviewed with a third boy their age who were found playing together in the gutter after a rain. They were fishing with their hands and a bottle for small swimming creatures. The third still slept with his father in a street shelter but the three begged together on the street for food and money. They bathed in the lake and used the gutters as toilets. They complained of threats of violence and theft by older boys ("who have homes").

One child, an eight-year-old, had been born to parents who begged. At age five he ran away after his mother intentionally burned his hand, leaving him disabled from the scarring. It is possible, though the question was not asked, that this was done to improve the family's income from begging. At first he was unwilling to tell us the story, later explaining that he feared that we might report his mother, with whom he no longer had any contact, though both parents remain on the streets. Another boy, a five-year-old, was interviewed with his mother who lived in a Sidama house in a neighboring town and had come into town with her regularly throughout his life to 
beg house to house. He was the youngest of six children and his father was dead.

The two girls born on the street lived with their mothers and begged with them or alone on the street and sometimes house to house. One of them had been born on the pavement in the central square of the town soon after her mother moved to Hawassa and found herself homeless. Mother and child continued to live on the street and this child, like the homeless boys, reported threats and theft. The second girl lived with her mother in Qrchu. They both planned to go to school the next year.

Those who were born on the street were much less likely to have attended school than the children in the other two groups, and those who did enter school dropped out in the first year.

Living with a parent, not born on the street. A second group consisted of five children who were still living with one parent, and though they had not been "born on the street," their lives were similar to those of the first group. In all cases their mothers had been forced into extreme poverty at some time after their births, to beg or sell bread (enjera) house to house. Three children came from Hawassa. Two had suffered the death of a supporting parent, while the mothers of the rest had separated from or been abandoned by their husbands, with alcoholism playing a role in each separation. As a group they were older than the children born on the street, with an average age of 11.6 years, and all of them lived in permanent structures. Probably in part due to their older age, all of them had been to school and, perhaps consistent with the presence of a parent, three of them were still attending. The oldest, the fifteen-year-old son of a woman who had come to Hawassa to treat her HIV infection, was in the third grade.

Since they were older than the first group, when they begged they did so alone instead of with their mothers. One said he had begged in the past but now only did street jobs. Two half-sisters, ages ten and thirteen, lived with their mother, a beggar who had been provided with a tin-roof permanent structure at St. Gabriel's. They were street-savvy and thoughtful about their position. Both now begged alone, although the older stated that she shared her takings with her family. She had left school after three years for lack of funds, but the younger had made it to fifth grade and was still in school. Their mother cooked for them, and they also worked at "street jobs"-washing dishes for food, carrying things. The older girl said she had tried selling single cigarettes, but they had been stolen and she had quit that work. One ten-year-old first-grade boy stated that he begged specifically for school supplies.

All but one complained of violence, theft, and threats of violence. The thirteen-year-old girl, when asked about sexual predators, stated that rich men in cars propositioned her but that she told them to "go and sleep with your money."

Left home for the street, independent. The third group, the largest, was composed of fifteen boys who had not been born on the street and were not still living with their parents. The oldest was seventeen, the youngest 
was ten, and the average age of the group was 12.5 years. Only two of the fifteen had been born in Hawassa, and nine had parents living more than twenty miles away. Three of them had found street shelter for which together they paid $3 \mathrm{birr} /$ night (USD0.16). The rest were all sleeping on the street, unprotected under a merchant's awning or in clothing bags. In this group the average age at which the child had begun to beg or do street jobs was just under twelve, later than among the members of the other groups. They were less likely than the others to have suffered the death of a parent, and seven had both parents still alive and living together. Only one had a parent who begged in a nearby town.

All those children whose parents were alive and living together had left or been sent from home because of inadequate support for the child. Eight of the fifteen, identified their parents as farmers who were unable to support their children except, in a few instances, during the harvest when extra labor was needed and extra food was available. Twelve of the fifteen said that their parents were very poor. The other three had left home because of conflict and violence or refusal of support, though there seemed to be adequate income. Two of those three had fathers who had remarried a stepmother. Of note, there were no girls in this group, perhaps indicating an unwillingness on the part of families to send girls away or to allow daughters to leave the home for a life on the street.

Interviews with three preteens selling toothbrush sticks by Lake Hawassa were particularly revealing. All three said that they were sent from their homes in Yrga Alem, just over twenty miles away, because their parents could not support them. Two had farming parents who lived together but told their children that there was only enough food for everyone during the coffee harvest season and that they should come back at that time. The third friend's father had died and he described his mother as old and poor.

Family pressure to leave due to poverty was a theme in several of the children's stories. One twelve-year-old had lived with his father, an alcoholic, after his mother left home. He had been beaten and sent away to Hawassa, and when he tried to return at Easter his father would not recognize him.

Six of these fifteen children mentioned beating by their parents as a factor in their leaving. Paralleling their dislocation from family, only one boy in this group continued to go to school. The educational level achieved was low, averaging less than three years, though all but one had attended school at some point.

All but one in this group worked. The exception was a very small elevenyear-old boy who stated he was too weak to carry things. However, all but two continued to beg to survive.

Interestingly, the boys in this group, possibly because they were older than the others and were more likely to be from out of town, had the dimmest view of the local police. A majority, nine boys, saw the police negatively, complained of beatings, false jailings, or being returned to their hometowns. 


\section{Discussion}

Both women and children living on the streets suffered from extreme poverty; hunger was an ever-present concern, as was physical safety. Previous academic research (e.g., Kilbride 2010) has focused on the agency of street children, in response to their summary categorization as objects of pity and the focus for fundraising. Our study found that though children were extremely clever and adaptive to their environment, that environment was harsh, painful, and frightening, and had not been chosen by the children. Instead, they were forced into it by the poverty of their families who could not support them, often compounded by the death of a parent (usually the father), separation of the parents, and violence. Many of the demographic and sociological features of our study group match those of Dube (2014), Mushir (2012), and Abebe (2008). Heinonen (2011) points to the role of gangs as social support networks, but this was not an outstanding finding in our Hawassa study.

More than one-fourth of the children were born to street women and had begged with them and thus were the second generation on the street. These children were younger than the group as a whole. A smaller group slept at home with their mothers but went to the street to find means outside the home to supplement what their mothers could provide. The third group, the oldest, consisted of young boys who had left home, some from far away, to find work in the city. They lived in makeshift shelters or on the pavement, worked odd jobs, and sometimes begged, because their families were unable to support them. Their parents were often still together but impoverished; several came from farming families who could only provide for them during the harvest.

The children's level of schooling was low, averaging less than three years, with the most common reason for leaving school being an inability to pay for school supplies and shoes. Most of those who were older than eight said that they had come to the streets looking for jobs, and some had been promised jobs by friends from their region who had preceded them to Hawassa. None had found housing in a permanent structure, all were hungry, and most had suffered threats and violence. None stated that they wished to stay on the street, and most had dreams for a better life.

The findings from the survey of street women echo many of those from the survey of street children. Three of these women were themselves "born on the street" and began begging with their parents. Only one was no longer begging but working (as was her husband), raising three children (with two in school), and living in a permanent structure. We also interviewed elderly women who had been begging for as long as thirty-eight years. Street women were almost always from poor families, had little or no education, and had suffered the death of a parent. Paralleling many of the children's trajectories to the street, most of these women were forced into begging and/or homelessness with the abandonment, disability, or death of a spouse. 
The women were less likely than the children to have come from the Hawassa area; less than half were born within a twenty-mile area, probably due to their greater mobility as adults. Fully half came to the city looking for jobs, but only 20 percent were working as well as begging at the time they were interviewed. Street jobs require hard physical labor and women with small children are less likely to be able to take advantage of what is available. All women begged with their small children if they had them (see figure 4).

Unlike the children, most of the women were living in permanent structures, with less than a third sleeping on the pavement or in street shelters. This was due in great part to the forced gathering of the homeless from the downtown into structures at Qrchu and St. Gabriel's, although these initiatives seem to have targeted only adults or families. In Qrchu their lives improved, as they were given access to water and rudimentary toilets as well as protection from rain, cold, and violence.

The women were far more likely to suffer from illness than were the children (84 percent versus 33 percent), yet they rarely sought or received

Figure 4. Young mother with child, Hawassa

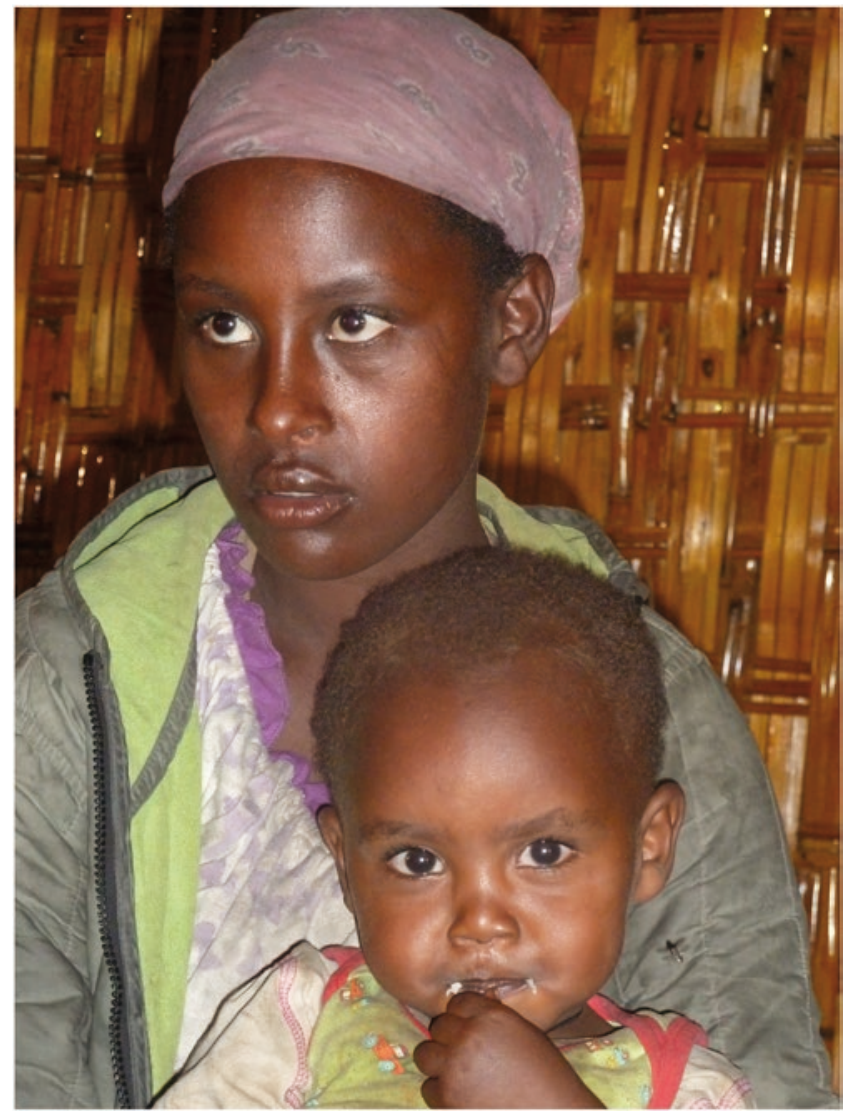


medical care. Nevertheless, they obtained immunizations and healthcare for their children. Like the children, women complained of hunger, although fewer complained of either violence, robbery, or threats of violence. At the same time, they were less likely than the children to view the police positively, as protectors rather than as harassers, or to cite shopkeepers as supportive, partly in terms of providing them with a "base" for storing their meager possessions during the day. The clear majority of both groups relied on the charity of the church for food and clothing donations at the holidays as the sole nonprofit giving them support. The municipality seems to have made food available to some, though older women remembered money donations from the city.

In general, women made less per day from begging than older male children could earn in their street jobs, although even the strongest teens were making less than USD2/day. One women was living on a reported daily income of 3 birr (USD0.16).

\section{Recommendations for Improvement of the Lives of Street Women and Children in Hawassa}

This study was undertaken with the assumption, borne out by the results, that street women and children suffer from their status and that desired alternatives are unavailable to them. Our findings identified the primary cause of street dependence and homelessness as poverty and either lack of work or wages/agricultural remuneration insufficient to support a family. Secondary and intersecting causes were the death or disability of, or abandonment by, a supporting partner or parent. Both government and nongovernmental organizational interventions up to this point have been inadequate to provide food, clothing, shelter, healthcare, sanitation, security, and education to meet their needs.

These findings are in no way unique in pointing to the need for the provision of jobs with adequate wages and support for small farmers. Ethiopia has been praised by the World Bank for its Productive Safety Net Programme, which among other services provides employment for impoverished men and women to build roads and public structures (World Bank $2015 \mathrm{~b})$. However, this program only provides a limited number of jobs offering very low wages (15 birr/day [USD0.85]) for no more than five days a month. Furthermore, these jobs are performed under harsh conditions, with high physical demands, and with no provision of childcare, which prevents many impoverished and malnourished women from participating. Some of the older children could conceivably participate, but not the younger ones, who should instead be in school in accordance with U.N. Millennium Development Goals.

To some degree the Ethiopian government recognizes the enormity of the problem of poverty among both urban and rural populations. Certain government agencies, such as the Ministry of Women, Children and Youth Affairs, recognize problems of unemployment, domestic violence, and legal 
rights, but they are underfunded and cannot address them adequately. The Hawassa municipal government does provide some shelter to homeless women in the form of housing at Qrchu, but it is not clear if the objective is to remove beggars as an eyesore or to provide a genuine social service. The government to some extent relies on local and international NGOs to provide social services, including reproductive healthcare, food aid, housing, medical care, education, and orphanages. A Mother Teresa Home and SOS Children's Village serve Hawassa and provide important services, but their reach is limited (SOS 2015).

The prevention of maternal and youth homelessness and street dependency requires the financial support for single women, children, and the disabled, and these programs should be administered by government agencies as much as possible-both in Ethiopia and elsewhere. Laws requiring industry to provide pension and worker compensation for injury and death are long overdue. There are other policies that, though smaller in scope, would remove some of the pressures on children and their families. Many children and mothers stated that attending school was impossible due to the need for shoes and supplies. We recommend school feeding programs to attract street children, and the provision of clothes, shoes, and supplies to school children in need. Though schooling is free in Ethiopia, it is clear from our observations that these necessities must be provided in order for education to be truly accessible to all.

Medical care is available to these women and children, but at a price. Though the cost is low ( 2 birr [USD0.11] was needed to be seen in the local hospital clinic), it was a clear hardship for these impoverished people. Immunizations are free and required, improving the state of health of the street population. We recommend universal access to health care that does not stigmatize the poor who are often turned away from hospital and clinic doors.

Finally, women and children suffer from the lack of financial and legal empowerment. No women to whom we spoke had received child support from men who had abandoned them or forced them to leave due to violence. Further, law enforcement seemed to provide women and children with no protection from violent or abusive spouses or parents. Several university law departments, including Hawassa University, offer legal counseling free of charge, as does the Center for Human Rights in Addis Ababa. Integration of these services with municipal offices could provide the support and protection necessary to keep poor women and children off the street.

\section{Acknowledgments}

This study is based on research conducted between October 2011 and May 2012 while the authors were U.S. Fulbright Scholars teaching in the Department of Medicine and the Department of Anthropology at Hawassa University, SNNPR Region of Ethiopia. We are grateful for the assistance of the 
women and children of Hawassa who participated in our study; we have purposely not used their full names. We wish to thank Dagim Alemayehu, then a student at Hawassa University, who was instrumental in setting up interviews and translating interviewees' comments into English from several languages (Amharic, Oromo); his dedication, skill, and commitment were invaluable to this project. We would also like to thank Sadie Gold-Shapiro and Sarah Liggera, students at Smith College, who helped with library and online research. We are grateful to the faculty and chairs of the Departments of Medicine and the Anthropology Program of the Department of Behavioral Sciences at Hawassa University, and for discussions with colleagues Awoke Amzaye Assoma, Beza Negewo, Mulye Girma Tadesse, and Walelign Tadesse Robele. Finally, we are grateful to the Fulbright Scholars Program, United States Department of State, for its support and assistance, and to the helpful assistance of the U.S. Embassy in Addis Ababa. The views expressed here are the authors' alone.

\section{References}

Abbink, J. 2006. "Discomfiture of Democracy? The 2005 Election Crisis in Ethiopia and its Aftermath." African Affairs 105 (419): 173-99.

Abebe, Tatek. 2008. "Earning a Living on the Margins: Begging, Street Work, and the Socio-Spatial Experiences of Children in Addis Ababa." Geografiska Annaler Series B. Human Geography 90 (3): 271-84.

Bahru, Zewde. 2001. A History of Modern Ethiopia, 1855-1991. Oxford: James Currey. Barrow, Ondine. 2001. "International Responses to Famine in Ethiopia 1983-85: Christian Aid and Political Economy Framework for Action." In The Charitable Impulse: NGOs and Development in East and North-East Africa, edited by Ondine Barrow and Michael Jennings, 63-80. Oxford: James Currey.

Berman, Bruce, and John Lonsdale. 1992. Unhappy Valley: Conflict in Kenya and Africa: Book One: State and Class. London: James Currey.

Campbell, John 2001. "Drawing a Line Between Autonomy and Governance: The State, Civil Society, and NGOs in Ethiopia." In The Charitable Impulse: NGOs and Development in East and North-East Africa, edited by Ondine Barrow and Michael Jennings, 149-66. Oxford: James Currey.

Central Statistical Agency, Ethiopia. 2007. Southern Peoples, Nations and Nationalities Region (SNNPR), Census 2007. www.csa.gov.

Connolly, Mark, and Judith Ennew. 1996. "Introduction: Children Out of Place." Childhood 3 (2): 131-45.

Dercon, S., and P. Krishnan. 2000. "Vulnerability, Seasonality and Poverty in Ethiopia." Journal of Development Studies 36 (6): 25-53.

Dercon, S., J. Hoddinott, and T. Woldehanna. 2012. "Growth and Chronic Poverty: Evidence from Rural Communities in Ethiopia." Journal of Development Studies 48 (2): 238-53.

Dube, Dharmendra. 2014. "The Status, Challenges, and Expectations of Homeless People in Ethiopia: A Case Study of Bahir Dar." European Academic Research 2 (2): 3027-44.

Fekadu, A., et al. 2014. "Burden of Mental Disorders and Unmet Needs among Street Homeless People in Addis Ababa, Ethiopia.” BMC Medicine 12 (1): 1-25. 
Fratkin, Elliot. 2014. "Ethiopia’s Pastoralist Policies: Development, Displacement and Resettlement." Nomadic Peoples 18 (1): 94-114.

Freund, W. 1996. "Economic History in South Africa: An Introductory Overview." South African Historical Journal 34: 127-50.

Futures-Agriculture. 2006." Land, Land Policy and Smallholder Agriculture in Ethiopia." http:/ / www.future-agricultures.org.

Government of Ethiopia (GoE). 2010. "Productive Safety Net Programme Implementation Manual (PIM).” Addis Ababa: Ministry of Agriculture.

- 2015. "Ethiopia Ministry of Women, Children and Youth Affairs and European Union Train 2250 Women and Help Them Find a Job." Ministry of Women, Children, and Youth Affairs. http:/ / reliefweb.int.

Heinonen, Paula. 2011. Youth Gangs and Street Children: Culture, Nurture and Masculinity in Ethiopia. New York: Berghahn Books.

Human Rights Watch. 2012. "Waiting Here for Death: Forced Displacement and "Villagization" in Ethiopia's Gambella Region." www.hrw.org.

—. 2014. “'Where Do You Want Us to Go?’ Abuses against Street Children in Uganda, July 17, 2014." www.hrw.org.

Iliffe, John. 1987. The African Poor: A History. Cambridge, U.K.: Cambridge University Press.

Kilbride, Philip L. 2010. "A Cultural and Gender Perspective on Marginal Children on the Streets of Kenya." Childhood in Africa 2 (1): 38-47.

Kilbride, Philip, Collette Suda, and Enos Njeryu. 2001. Street Children in Kenya: Choices of Children in Search of a Childhood. Westport, Conn.: Bergin and Garvey.

Little, Peter D. 2014. Economic and Political Reform in Africa: Anthropological Perspectives. Bloomington: Indiana University Press.

Markus, Harold G. 2002. A History of Ethiopia. Berkeley: University of California Press.

Mushir, Ali. 2012. "Socio-Economic Analysis of Homeless Population in Urban Areas: A Case Study of Northern Ethiopia.” International Journal of Scientific and Research Publication 2 (8): 1-8.

Nathan, M. A., et al. 2005. "Health and Morbidity among Rendille Pastoralist Children: Effects of Sedentarization." In As Pastoralists Settle: Social, Health, and Economic Consequences of Pastoral Sedentarization in Marsabit District, Kenya, edited by E. Fratkin and E. A. Roth, 193-208. New York: Springer Publishing.

Oakland Institute. 2011. "Understanding Land Investment Deals in Africa: Ethiopia Country Report." www.oaklandinstitute.org.

Olufemi, Olusola. 1999. "Health of the Homeless Street Women in South Africa." Habit International 23 (4): 481-93.

Overseas Development Institute (ODI). 2006. “Targeting Ethiopia's Productive Safety Net Programme (PSNP).” www.odi.org.

Panter-Brick, Catherine. 2002. "Street Children, Human Rights, and Public Health: A Critique and Future Directions." Annual Review of Anthropology 31: 147-71.

Phiri, C. M., and B. E. Perron. 2012. "Health Implications of Chronic Homelessness: Lived Experiences of Adult Men and Women at a Community in Gauteng Province, South Africa." African Journal for Physical, Health Education, Recreation E Dance 18: 160-73.

Roelen, Keetie, and Laura Camfield. 2014. "Universal Truths or Hidden Realities: Chronic Poverty in Rural Ethiopia." Journal of International Development 26: $1024-38$. 
SOS Children's Villages International. 2015. "SOS Children’s Village Hawassa." www.sos-childrensvillages.org.

Tekola, Bethlehem, Christine Griffin, and Laura Camfield. 2009. "Using Qualitative Methods with Poor Children in Urban Ethiopia: Opportunities and Challenges." Social Indicators Research 90 (1): 73-87.

Tipple, Graham, and Suzanne Speak. 2005. "Definitions of Homelessness in Developing Countries.” Habitat International 29 (2): 337-52.

UNESCO. 2015. "Street Children. "www.unesco.org.

World Bank. 2009. "Project Appraisal Document for Phase Three of the Productive Safety Net Program.” Washington, D.C.: World Bank.

—. 2015a. "Urbanization in Africa: Trends, Promises, and Challenges." www. worldbank.org.

—. 2015b. "Ethiopia Poverty Assessment 2014." Washington, D.C.: World Bank. https://openknowledge.worldbank.org.

—. 2015c. "World Bank Group Supports Improved Livelihoods of Urban Poor." aigaforum.com.

—. 2016. "Ethiopia: Urban Productive Safety Net Project." http://documents. worldbank.org.

Yntiso, Gebre. 2008. "Urban Development and Displacement in Addis Ababa: The Impact of Resettlement Projects on Low-Income Households." Eastern Africa Social Science Research Review 24 (2): 53-77. 